Creative Commons User License: CC BY-NC-ND

Abstracted by: EBSCOhost, Electronic Journals Service (EJS),

Google Scholar, Journal Seek, Scientific Commons,

Food and Agricultural Organization (FAO), CABI and Scopus

http://eoi.citefactor.org/10.11226/v25i2
Journal of Agricultural Extension

Vol. 25 (2) April, 2021

ISSN(e): 24086851; ISSN(Print); 1119944X

http://journal.aesonnigeria.org

http://www.ajol.info/index.php/jae

Email: editorinchief@aesonnigeria.org

\title{
Influence of Internet-based Mobile Phone Applications on Employees Job Commitment in Agricultural Research Institutes in Oyo State, Nigeria https://dx.doi.org/10.4314/jae.v25i2.4
}

\section{Oose, Mathew Olekan}

Department of Agricultural Administration, College of Agricultural Management and Rural Development, Federal University of Agriculture, Abeokuta, Nigeria

Email: oosemo@funaab.edu.ng, Phone: +2348060348644

\section{Fapojuwo, Oluwakemi E.}

Department of Agricultural Administration, College of Agricultural Management and Rural Development, Federal University of Agriculture, Abeokuta, Nigeria

Email: kemifapojuwo@gmail.com, Phone:+2348062403148

\section{Agbabiaka, Jibril A.}

Department of Agricultural Administration, College of Agricultural Management and Rural Development, Federal University of Agriculture, Abeokuta, Nigeria

Email: jibrilagbabiaka@gmail.com, Phone:+2348130055819

\section{Abstract}

This study assessed factors influencing the use of internet-based mobile phone apps on employees on job commitment in agricultural research institutes in Oyo State, Nigeria. A multistage sampling procedure was used to select 94 employees. The data were obtained through a structured questionnaire and analyzed using percentages, chi-square analysis and principal component analysis (PCA). Result showed that Whatsapp ( $\bar{x}=3.32$ ), Emails $(\bar{x}=3.23$ ) and Opera mini $\bar{x}=3.23)$ were the most frequently used internet-based mobile phone apps. The use of internet-based mobile apps enhances their job commitments ( $\bar{x}=3.86)$ while using internet-based mobile apps saves time $(\bar{x}=3.54)$. Fluctuations of internet connectivity $(\bar{x}=2.71)$ and epileptic power supply $(\bar{x}=2.36)$ were factors influencing the use of internet-based mobile phone apps. Significant relationship ( $P \leq 0.05)$ existed between employees use of whatsApp $\left(X^{2}=9.80\right)$, Email $\left(X^{2}=6.60\right)$ and Instagram $\left(X^{2}=-16.0\right)$ and job commitment. $P C A$ reveals that fluctuation of internet connectivity (0.78) was the major determinants of employees' use of internet-based mobile phone apps. It was concluded that whatsapp and emails positively influenced employees' commitment to their job with favourable and positive perceive ease of use of these internet-based mobile apps. Therefore, the study recommended that stable and functional internet facilities 
Creative Commons User License: CC BY-NC-ND

Abstracted by: EBSCOhost, Electronic Journals Service (EJS),

Google Scholar, Journal Seek, Scientific Commons,

Food and Agricultural Organization (FAO), CABI and Scopus

http://eoi.citefactor.org/10.11226/v25i2
Journal of Agricultural Extension

Vol. 25 (2) April, 2021

ISSN(e): 24086851; ISSN(Print); 1119944X

http://journal.aesonnigeria.org

http://www.ajol.info/index.php/jae

Email: editorinchief@aesonnigeria.org

should be in agricultural research institutes to enable employees explore the potentials of internet-based mobile phone apps.

Keywords: Internet-based mobile phone apps, job commitment, employees, agricultural research institutes

\section{Introduction}

The critical role of communication in ensuring employees' workplace commitment still remains one of the most intriguing and challenging concepts in almost every organization in developing countries. As a matter of fact, communication in the fields of organizational behaviour and human resources management in becoming more relevant with the emergence of new information and communication technologies (ICTs). Prior to the advent of mobile phones, workplace employees were extremely constrained to communicate with each other while at work. They are sometimes cut off from all activities that affect their work commitment while the existing linear workplace information system from top-management to middle-level and finally to lower-level employees has been criticized as been too expensive and cumbersome. This linear model has limited capacity to generate feedback on the quality of information. Hence, the integration of mobile phone apps, particularly internet-based apps to organizations' development communication and information delivery may help to develop an open system where employees' workplace commitment is not only ensured but enhanced (Oose, 2017).

According to the World Bank (2019), Mobiles especially have become the most ubiquitous communication technology in the developing world where the subscription rates have soared from 700 million to over 6.8 billion with the developing countries responsible for about 77 percent of the subscription. Mobile phones have long been utilized for development communication and it constituted part of the revolution brought to the transfer and dissemination of information (Oose, Banmeke and Olaoye, 2017; Oose, 2019). However, before the invention of internet-based mobile phone apps, mobile phones were limited in its operations (Edgar Snyder \& Associates, 2016).

To address the limitations of mobile phones, the use and integration of internetbased mobile apps at workplace is quite expedient. Attaran \& Attaran (2019) noted that rapid advancement of technology and developments in the information and communication technologies have made the internet-based apps an indispensable component of employees in the workplace. It is seen that internet-based apps are the most rapid and effective way of accessing information in the 21 st century. Consequently, internet-based mobile apps consist of software that runs on a mobile 
Creative Commons User License: CC BY-NC-ND

Abstracted by: EBSCOhost, Electronic Journals Service (EJS),

Google Scholar, Journal Seek, Scientific Commons,

Food and Agricultural Organization (FAO), CABI and Scopus

http://eoi.citefactor.org/10.11226/v25i2
Journal of Agricultural Extension

Vol. 25 (2) April, 2021

ISSN(e): 24086851; ISSN(Print); 1119944X

http://journal.aesonnigeria.org

http://www.ajol.info/index.php/jae

Email: editorinchief@aesonnigeria.org

device, perform certain tasks for the user. Internet-based mobile apps is easy, user friendly, inexpensive, downloadable and runnable in most of the mobile phones including inexpensive and entry level phones. Also, it has wide use for its vast functioning area like calling, messaging, browsing, chatting, social network communication, audio, video, games among others (Ang, 2017; Islam and Mazumder, 2017). Other categories of internet-based mobile apps are email, social networking, puzzle, cards, graphics, image viewer, video players, audio players, calendars, calculators, diary, notepad, memo, word processors, spreadsheets, converter, GPS, maps and others. According to the Turkey Statistics Institution (2016), more than 80 percent of the individuals using the internet-based mobile apps created a profile, sent message or shared content such as photograph through the social media; $70.2 \%$ used internet-based mobile apps for reading online news, newspaper or magazine; $66.3 \%$ use them at workplace and $62.1 \%$ uploaded content such as text, image, photograph, video, music to share via any website. Also, it was noted that about $42.5 \%$ using internet-based mobile apps were between the ages of 16 and 74 used internet at workplace.

Given credence to the foregoing, internet-based mobile phone apps enable employees to organize their work; gives more opportunity to be creative and efficient in scheduling work and meetings. Internet-based mobile phone apps also give an opportunity to individualize work and provide physical freedom of movement in work. Internet-based mobile phone apps enable users to collaborate digitally with peers, constructing knowledge digitally (Schindler, Burkholde, Morad \& March, 2017). It was observed that younger employees with a millennial mind-set find it hard to draw the line between their personal and professional lives as well as seek the flexibility and ease-of-use that their personal devices provide (Karthikeyan, 2017). Flexibility in the workplace allows employers and employees to make arrangements about working conditions that suit them. This helps employees maintain a work-life balance and enable employers improve the productivity and efficiency of their business (Pathak, Dubey and Deepak, 2019).

On the contrary, mobile phone-based interference to job tasks included drawbacks such as receiving information from social networks which cannot be handled by individuals while at work, receiving information that are not useful for work and getting distracted from work. Also, frequent use of internet-based mobile apps causes stress, insomnia and depression. Other physical symptoms include headaches, ear ache, warmth sensation and fatigue. The dual use, that is, work and non-work use of Internet-based mobile phone apps has resulted in a merger of work and personal life. The deviant use of internet-based mobile apps may distract 
Creative Commons User License: CC BY-NC-ND

Abstracted by: EBSCOhost, Electronic Journals Service (EJS),

Google Scholar, Journal Seek, Scientific Commons,

Food and Agricultural Organization (FAO), CABI and Scopus

http://eoi.citefactor.org/10.11226/v25i2
Journal of Agricultural Extension

Vol. 25 (2) April, 2021

ISSN(e): 24086851; ISSN(Print); 1119944X

http://journal.aesonnigeria.org

http://www.ajol.info/index.php/jae

Email: editorinchief@aesonnigeria.org

(engage in non-work purposes) employees from job tasks on hand and engage in unproductive or unethical activities such as online shopping, news, music, chatting, auctioning and games while at work. Mercurio (2015) defined workplace commitments as a core predictor of employees' attitude to the organization/work effectiveness or employees' psychological attachment towards his/her organization, and a force that guides a course of action of employees towards one or more targets. It is therefore important to examine whether or not internet-based mobile apps determine or influence employees' job commitment in agricultural research institutions in south-west, Nigeria.

\section{Objective of the study}

This paper examined the influence of internet-based mobile apps on employees' job commitments in agricultural research institutes in Oyo State. The specific objectives of the study include to: ascertained the socioeconomics characteristics of the respondents, brands of mobile phones used, and frequency of use of internet-based mobile apps, perceived ease of use of internet-based mobile apps, employees' job commitments and factors influencing the use of internet-based mobile apps. The study hypothesized that no significant association exist between internet-based mobile apps and job commitments and factors influencing the use of internet-based mobile apps are not significantly related.

\section{Methodology}

The study was carried out in Oyo State, southwest geopolitical zone of Nigeria with the coordinate of $8.157^{\circ} \mathrm{N}$ and $3.0147^{\circ} \mathrm{E}$. The study population were all the employees of the agricultural research institutes in Oyo State Nigeria. Two stage sampling procedure was used to select respondents for the study. The first stage involved the random selection of three (3) out of the seven (7) agricultural research institutes namely; the Institute of Agricultural Research and Training (IAR\&T) in Ibadan, Forest Research Institute of Nigeria (FRIN) in Ibadan and Cocoa Research Institute of Nigeria (CRIN) in Onigambari from where the list of the respondents from these three institutes were generated. This gave a total of 407 respondents (144 from Institute of Agricultural Research and Training, 125 from Forest Research Institute of Nigeria and 138 from Cocoa Research Institute of Nigeria) from the three institutes so far as at the year 2018. The second stage involves the random selection of respondents using Watson (2001) sampling size determination at variance in sample size determination of $0.23 \%$ of the total respondents of the selected agricultural institutions which gave a sample size of 94 respondents used for this study. 
Creative Commons User License: CC BY-NC-ND

Abstracted by: EBSCOhost, Electronic Journals Service (EJS),

Google Scholar, Journal Seek, Scientific Commons,

Food and Agricultural Organization (FAO), CABI and Scopus

http://eoi.citefactor.org/10.11226/v25i2
Journal of Agricultural Extension

Vol. 25 (2) April, 2021

ISSN(e): 24086851; ISSN(Print); 1119944X

http://journal.aesonnigeria.org

http://www.ajol.info/index.php/jae

Email: editorinchief@aesonnigeria.org

Frequency of use of internet-based mobile app by the respondents was measured by rating 12 types of internet-based mobile apps with the response options of 'very often', 'sometimes', 'rarely' and 'never' with scores of 3,2, 1 and 0 assigned respectively. Minimum obtainable score was 0 and maximum was 36 . The weighted mean score was generated and used to rank their responses to determine the most frequently used internet-based mobile apps. The perceived ease of use of internetbased mobile apps was measured by a list of eleven perceptual statements with the response options of strongly agree, agree, undecided, disagree and strongly disagree with score of 5,4,3,2, and 1 assigned respectively for all positive statements and was reversed for the negatively worded statements. The maximum obtainable score was 55 with the minimum score of 11.

To measure the employees job commitment, 10 job commitments statements with the response options of strongly agree, agree, undecided, disagree and strongly disagree with score of 5,4,3,2, and 1 assigned respectively for all positive statements and was reversed for the negatively worded statements. The maximum obtainable score was 50 with the minimum score of 10 . The factors influencing the use of internet-based mobile apps was measured by providing them with a list of eight factors such as fluctuation of internet connectivity, epileptic power supply, lack of finance, inadequate knowledge and complexity of mobile app operation among others. They were asked to state the severity of each factor with response option "severe constraint" was assigned a score of 2, "mild constraint" a score of 1 and not a constraint was assigned 0 . Minimum obtainable score was 0 and maximum 16. Weighted score was generated and used to rank the factors to determine the severity.

Data were analyzed using percentages, mean, standard deviation, chart, the Chisquare test and the Principal Components Analysis (PCA). The Eigen value of one (1) criterion was used as the limit for selecting the number-of-components problem. Factor loading was used to determine the variable that forms variables that loaded from 0.70 and above were considered significant. The rotated component/factor matrix was used to find the correlation between the variable and the factor. Furthermore, the total variance explained was used in this study to determine the percentage contribution of each factor or component retained in the factor analysis, while the principal component analysis was used to determine the number of uncorrelated variables that form a component or factor. The principal component factor analysis model is stated thus:

$\mathrm{Y} 1=\mathrm{a} 11 \mathrm{X} 1+\mathrm{a} 12 \mathrm{X} 2+{ }^{* * *}+\mathrm{a} 1 \mathrm{nXn}$

$\mathrm{Y} 2=\mathrm{a} 21 \mathrm{X} 1+\mathrm{a} 22 \mathrm{X} 2+{ }^{*} * *+\mathrm{a} 2 \mathrm{nXn}$

$\mathrm{Y} 3=\mathrm{a} 31 \mathrm{X} 1+\mathrm{a} 32 \mathrm{X} 2+{ }^{* *}+\mathrm{a} 3 \mathrm{nXn}$ 
Creative Commons User License: CC BY-NC-ND

Abstracted by: EBSCOhost, Electronic Journals Service (EJS),

Google Scholar, Journal Seek, Scientific Commons,

Food and Agricultural Organization (FAO), CABI and Scopus

http://eoi.citefactor.org/10.11226/v25i2
Journal of Agricultural Extension

Vol. 25 (2) April, 2021

ISSN(e): 24086851; ISSN(Print); 1119944X

http://journal.aesonnigeria.org

http://www.ajol.info/index.php/jae

Email: editorinchief@aesonnigeria.org

$\mathrm{Yn}=\mathrm{an} 1 \mathrm{X} 1+\mathrm{an} 2 \mathrm{X} 2+{ }^{*}{ }^{*}+\mathrm{annXn}$

Where

$\mathrm{Y} 1, \mathrm{Y} 2 \ldots \mathrm{Yn}=$ factors influencing the use of internet-based mobile apps

a1 - an $=$ factor loadings or correlation coefficients.

$\mathrm{X} 1, \mathrm{X} 2, \ldots \mathrm{Xn}=$ unobserved underlying factors constraining the use of internet-based mobile apps

\section{Results and Discussion}

\section{Usage of Internet-Based Mobile Apps}

Results in Table 1 show that WhatsApp ( $\bar{x}=3.32)$ was the most frequently used internet-based mobile apps at work. This is followed by emails $(\bar{x}=3.23)$ and opera mini $(\bar{x}=3.23)$ while the least used internet-based mobile apps was Myspace $(\bar{x}=33.4)$. This connotes that WhatsApp, emails and opera mini were mostly used for their daily work responsibilities, hence mobile apps play a vital role in the survival of any organization.

Table 1: Usage of internet-based mobile apps

\begin{tabular}{llll}
\hline S/N & $\begin{array}{l}\text { Internet-based } \\
\text { mobile apps }\end{array}$ & $\begin{array}{l}\text { Mean } \\
\text { value }\end{array}$ & $\begin{array}{l}\text { Standard } \\
\text { deviatio } \\
\text { ns }\end{array}$ \\
\hline 1 & Whatsapp & 3.32 & 0.72 \\
2 & Emails & 3.23 & 0.87 \\
3 & Opera Mini & 3.23 & 0.87 \\
4 & Instagram & 3.02 & 0.67 \\
5 & Twitter & 2.91 & 0.34 \\
6 & YouTube & 2.97 & 0.78 \\
7 & Maps & 2.71 & 0.91 \\
8 & Snapchat & 2.06 & 0.72 \\
9 & Facebook & 3.14 & 0.96 \\
10 & Skype & 2.38 & 0.94 \\
11 & Palmchat & 2.59 & 0.27 \\
12 & MySpace & 2.22 & 0.73 \\
\hline
\end{tabular}

Figure 1: Brands of mobile phones used by respondents

\section{Perceived Ease of Use of Internet-Based Mobile Apps}

Table 2 shows employees' perceived ease of use of internet-based mobile apps. It was noted that the use of internet-based mobile apps enhances employees' job commitments $(\bar{x}=3.86)$, internet-based mobile apps saves time $(\bar{x}=8.85)$ and makes work easier $(\bar{x}=0.74)$. This implies that the use of internet-based mobile apps enhances work commitments, improves productivity and not only create a workfriendly environment but makes employees see work as fun. This is consistent with 
Creative Commons User License: CC BY-NC-ND

Abstracted by: EBSCOhost, Electronic Journals Service (EJS),

Google Scholar, Journal Seek, Scientific Commons,

Food and Agricultural Organization (FAO), CABI and Scopus

http://eoi.citefactor.org/10.11226/v25i2
Journal of Agricultural Extension

Vol. 25 (2) April, 2021

ISSN(e): 24086851; ISSN(Print); 1119944X

http://journal.aesonnigeria.org

http://www.ajol.info/index.php/jae

Email: editorinchief@aesonnigeria.org

the findings of Bhatiasevi and Yoopetch (2015) in which employees had a favourable and positive perceived ease of use of internet mobile apps.

Table 2: Perceived ease of use of internet-based mobile apps

\begin{tabular}{|c|c|c|}
\hline Perceptual statement & $\begin{array}{l}\text { Mean } \\
\text { Value }\end{array}$ & $\begin{array}{l}\text { Standard } \\
\text { deviation }\end{array}$ \\
\hline $\begin{array}{l}\text { The use of internet-based mobile apps enhances my job } \\
\text { commitments }\end{array}$ & 3.86 & 0.39 \\
\hline $\begin{array}{l}\text { My interaction with internet-based mobile apps is quite easy for me } \\
\text { to understand }\end{array}$ & 3.54 & 0.20 \\
\hline Using internet-based mobile apps saves time & 3.85 & 0.25 \\
\hline $\begin{array}{l}\text { Using internet-based mobile apps enhances my effectiveness on the } \\
\text { daily work }\end{array}$ & 3.73 & 0.10 \\
\hline Using internet-based mobile apps makes it easier to do my work & 3.74 & 0.23 \\
\hline $\begin{array}{l}\text { My work duties will be difficult to perform without my use internet- } \\
\text { based mobile apps }\end{array}$ & 3.43 & 0.46 \\
\hline $\begin{array}{l}\text { Using internet-based mobile apps gives me greater control over my } \\
\text { work }\end{array}$ & 3.63 & 0.32 \\
\hline I find internet-based mobile apps useful in my job & 3.63 & 0.32 \\
\hline $\begin{array}{l}\text { Using internet-based mobile apps reduces the time I spent on } \\
\text { unproductive activities }\end{array}$ & 3.45 & 0.20 \\
\hline internet-based mobile apps support critical aspect of my work & 3.20 & 0.17 \\
\hline I often become confused when using internet-based mobile apps & 3.73 & 0.10 \\
\hline
\end{tabular}

Source: Field survey (2018)

\section{Employees' Job Commitment}

Table 4 show employees' commitment as influenced by their use of mobile internetbased apps. It was noted that institutional work challenges and responsibilities of the employees are theirs $(\bar{x}=3.73)$ this was made possible because of their use of internet-based mobile apps. In addition, it was noted that some of the employees were emotionally attached to their job $(\bar{x}=3.34)$ and this might be influenced by their frequent use of internet-based mobile app for their work activities. This connotes that employees are not only willing to exert considerable effort on behalf of their organization but possesses a strong desire to maintain membership in their organization. This is in consonance with the position of Mercurio (2015) that employees' commitments is a psychological attitude that determines workplace effectiveness. 
Creative Commons User License: CC BY-NC-ND

Abstracted by: EBSCOhost, Electronic Journals Service (EJS),

Google Scholar, Journal Seek, Scientific Commons,

Food and Agricultural Organization (FAO), CABI and Scopus

http://eoi.citefactor.org/10.11226/v25i2
Journal of Agricultural Extension

Vol. 25 (2) April, 2021

ISSN(e): 24086851; ISSN(Print); 1119944X

http://journal.aesonnigeria.org

http://www.ajol.info/index.php/jae

Email: editorinchief@aesonnigeria.org

\section{Table 4: Employees' Job Commitment}

\begin{tabular}{|c|c|c|}
\hline Job Commitment & $\begin{array}{l}\text { Mean } \\
\text { value }\end{array}$ & $\begin{array}{l}\text { Standard } \\
\text { deviation }\end{array}$ \\
\hline $\begin{array}{l}\text { I really feel as if my institutions work challenges } \\
\text { and responsibilities are my own }\end{array}$ & 3.73 & 0.18 \\
\hline $\begin{array}{l}\text { Job commitments will be better when I stayed } \\
\text { with my organization for most of their career }\end{array}$ & 3.06 & 0.08 \\
\hline $\begin{array}{l}\text { If I get another offer for a better job elsewhere, } \\
\text { I would not feel it was right to leave my organization }\end{array}$ & 2.70 & 0.02 \\
\hline $\begin{array}{l}\text { Jumping from organization to organization does not } \\
\text { seem unethical to me at all }\end{array}$ & 2.76 & 0.84 \\
\hline $\begin{array}{l}\text { I think I easily become attracted to another job as I } \\
\text { am to this one }\end{array}$ & 2.62 & 0.05 \\
\hline I do not feel a strong sense of belonging to my job & 2.80 & 0.21 \\
\hline $\begin{array}{l}\text { I do not feel wanting to be a researcher is sensible } \\
\text { Anymore }\end{array}$ & 3.07 & 0.03 \\
\hline $\begin{array}{l}\text { I do not believe that a person must always be committed } \\
\text { to his/her job }\end{array}$ & 3.13 & 0.12 \\
\hline I do not feel emotionally attached to this job & 3.34 & 0.01 \\
\hline I do not feel like part of the family of my job & 3.29 & 0.21 \\
\hline
\end{tabular}

Source: Field survey (2018)

\section{Factors Influencing Use of Internet-Based Mobile Apps}

Fluctuation of internet connectivity ranked first $(x=2.71)$ as the major factor influencing the use of internet-based mobile apps, followed by epileptic electricity supply $(\bar{x}=2.36)$, durability of battery $(\bar{x}=2.33)$ while the least factor is speed/cost $(\bar{x}=1.80)$. This indicates that if the phone and its internet connectivity is good, workplace commitment will be enhanced. This is in contrast with the assertions of Owusu-Marfo (2016) that stress, insomnia and distractions were factors affecting the use of internet-based mobile apps.

Table 5: Factors influencing use of internet-based mobile apps

\begin{tabular}{lll}
\hline Variables & Mean & Standard deviation \\
\hline Fluctuation of internet connectivity & 2.71 & 0.82 \\
Epileptic power supply & 2.36 & 0.72 \\
Durability of battery & 2.33 & 0.75 \\
Lack of window/size & 2.32 & 0.70 \\
Complexity/navigation & 1.84 & 0.75 \\
Lack of fund to purchase good phone & 1.93 & 0.71 \\
Small screen size & 1.96 & 0.77 \\
Speed/cost & 1.80 & 0.69
\end{tabular}

Source: Field survey (2018) 


\section{Association between Use of Internet-Based Mobile Apps and Job Commitment}

Tables 6 shows that WhatsApp $\left(x^{2}=9.80 ; d f=3\right)$, Emails $\left(x^{2}=6.60 ; d f=3\right)$ and Instagram $\left(X^{2}=-16.0 ; d f=3\right)$ among other internet-based mobile phone apps used by the respondents were significantly $(p \leq 0.05)$ related to employees' job commitments. However, whatsapp and emails were positively related to their job commitment while Instagram was negatively related. This implies that whatsapp and email were the identified internet-based mobile app that positively influenced employees' job commitment in the study area. Also, the more the use of Instagram the lower their job commitment. This is true because Instagram is more of pictures and more of advertisement of business which is nor relevant to employees in research institutes. This is expected because Whatsapp is widely used as an instant and digital communication tool which influence workplace communication.

Table 6: Association between internet-based mobile apps and job commitment

\begin{tabular}{lll}
\hline Variables & $\mathbf{x}^{\mathbf{2}}$ & $\mathrm{Df}$ \\
\hline Whatsapp & $\mathbf{9 . 8 0 ^ { * }}$ & 3 \\
Emails & $\mathbf{6 . 6 0 ^ { * }}$ & 3 \\
Opera Mini & 1.88 & 3 \\
Instagram & $\mathbf{- 1 6 . 0 ^ { * }}$ & 3 \\
Twitter & 6.06 & 3 \\
YouTube & 6.00 & 3 \\
Maps & 0.81 & 3 \\
Snapchat & 0.38 & 3 \\
Facebook & 3.76 & 3 \\
Skype & 2.58 & 3 \\
Palmchat & 1.52 & 3 \\
MySpace & 5.25 & 3 \\
\hline
\end{tabular}

${ }^{*} \mathrm{P} \leq 0.05$ Source: Field data 2018

$\mathrm{X}^{2}=$ Chi-square; $\mathrm{df}=$ degree of freedom;

\section{Factors Influencing the Use of Internet-based Mobile Apps}

Results in Table 7 show eight components and their corresponding Eigen values while the Eigen values greater than one (2.77) and (1.38) were considered and acceptable hence the first-two principals' components which account for over $51.94 \%$ of the total variability. However, the two variables retained in the model accounted for $51.9 \%$ of the variability. Table $7 \mathrm{~b}$ shows that fluctuation of internet connectivity (0.78) was significant. This implies that fluctuation in internet connectivity is a key factor that influenced the use of internet-based mobile apps by the employees in research institutes in Nigeria. 
Creative Commons User License: CC BY-NC-ND

Abstracted by: EBSCOhost, Electronic Journals Service (EJS),

Google Scholar, Journal Seek, Scientific Commons,

Food and Agricultural Organization (FAO), CABI and Scopus
Journal of Agricultural Extension

Vol. 25 (2) April, 2021

ISSN(e): 24086851; ISSN(Print); 1119944X

http://journal.aesonnigeria.org

http://www.ajol.info/index.php/jae

Email: editorinchief@aesonnigeria.org

Table 7: Factors influencing use of internet-based mobile apps

\begin{tabular}{lll}
\hline Variables & Factor I & Factor II \\
\hline Lack of fund to purchase good phone & 0.64 & 0.33 \\
Fluctuation of internet connectivity & $\mathbf{0 . 7 8}^{\star}$ & -0.41 \\
Small screen size & 0.56 & -0.03 \\
Epileptic power supply & 0.46 & 0.01 \\
Lack of window/size & 0.69 & 0.50 \\
Durability of battery & 0.46 & 0.56 \\
Complexity/Navigation & 0.65 & 0.45 \\
Speed/cost & 0.28 & 0.31 \\
\hline
\end{tabular}

Source: Field data2018

\section{Conclusion and Recommendation}

The most frequently used internet-based mobile apps on their mobile phone were Whatsapp and Emails. They favorably and positively perceived the ease of use towards internet-based mobile apps which in turn enhanced high job commitment. Also, fluctuation of internet connectivity was identified as factors influencing the use of internet-based mobile apps while significant association existed between the employees frequently use of Whatsapp, emails and their job commitment. In addition, fluctuations of internet connectivity are significantly related as the major factor influencing the use of internet-based mobile apps. Re-orientation and sensitization programmes should be given to employees on their effective use to enhance productivity at the work place. Employees' perceived ease of use of internet-based mobile apps should be worked-on so as to ensure its future influence on workplace commitment.

\section{References}

Attaran, M. and Attaran, S. (2019). The need for digital workplace: Increasing workforce productivity in the information age, International Journal of Enterprise Information Systems, 15(1); 23-34

Ang, C.S. (2017). Internet habit strength and online communication: Exploring gender differences. Computers in Human Behavior, 66: 1-6.

Bhatiasevi, V., and Yoopetch, C. (2015). The determinants of intention to use electronic booking among young users in Thailand. Journal of Hospitality and Tourism Management, 23, 1-11.

Edgar Snyder and Associates (2016). Cell Phone Driving Laws in the United States.

Retrieved from https://www.edgarsnyder.com/car-accident/cause-of-accident/cellphone/cell-phonelaws.htm|\#new-york 
Creative Commons User License: CC BY-NC-ND

Abstracted by: EBSCOhost, Electronic Journals Service (EJS),

Google Scholar, Journal Seek, Scientific Commons,

Food and Agricultural Organization (FAO), CABI and Scopus

http://eoi.citefactor.org/10.11226/v25i2
Journal of Agricultural Extension

Vol. 25 (2) April, 2021

ISSN(e): 24086851; ISSN(Print); 1119944X

http://journal.aesonnigeria.org

http://www.ajol.info/index.php/jae

Email: editorinchief@aesonnigeria.org

Islam and Mazumder (2017). Mobile applications and its global impacts International Journal of Engineering \& Technology 10(06); 103-111

Karthikeyan, C. (2017). A qualitative study on managing millennial mindsets: Awaiting challenges for HR strategists and recruiters, International Journal of Innovative Research in Engineering \& Management, 4(1); 600-609

Mercurio, Z.A. (2015). Affective commitment as a core essence of organizational commitment: An integrative literature review. Human Resource Development Review, 18(1); 1-17

Oose, M. O. (2019). Artisanal fishers utilization of short message services (SMS) for agricultural information in coastal Areas of South-west, Nigeria: Principal Component Analysis. Nigerian Agricultural Journal 50(1); 263-269. Published by the Agricultural Society of Nigeria. Available on http://www.ajol/info/index.php/nai

Oose, M. O., Banmeke, T. O. A. and Olaoye, O. J (2017) Artisanal fishermen's utilization of mobile phone application in coastal communities of South-Western, Nigeria: Implications for information dissemination. Ibadan Journal of Agricultural Research 12(2), 15-25. Published by Faculty of Agriculture and Forestry, University of Ibadan, Ibadan, Nigeria

Oose, M. O. (2017) Acceptability of Short Message Services for Information dissemination among Artisanal Fishers in Coastal areas of South Western, Nigeria. PhD Thesis submitted to the department of Agricultural extension and Rural development, Federal University of Agriculture, Abeokuta. $321 \mathrm{pp}$

Owusu-Marfo J. (2016). The impact of the use of mart mobile devices on sleep quality among health trainees at College of health and well-being, Kintampo, Ghana. B.Sc project submitted to the department of computer science, Wame Nkrumah University of Science and Technology, Kumasi. 89pp

Pathak, A. K, Dubey, P and Deepak, S. (2019). Work life balance and job satisfaction: A literature review, International Journal of Computer Sciences and Engineering, 7(3); $180-187$

Schindler, L.A., Burkholder, G.J., Morad, O. A and March, C. (2017). Computer-based technology and student engagement: a critical review of the literature. Internal Journal of Education Technology in Higher Education, 14(25); 2-28

Turkey Statistical Institute, (2016). Household Information Technology Usage Survey, Retrieved from: http://www.tuik.gov.tr/PreHaberBultenleri.do?id=18660

World Bank (2019). World Bank group annual report. Ending poverty, investing in opportunities. World Bank resources 